\title{
6 ．乳児喘息の治療
}

\author{
村上 巧啓 ${ }^{1)}$ ，松野 正知 ${ }^{2)}$ \\ 足立 雄一2), 五十嵐隆夫 ${ }^{3)}$ \\ (1)富山赤十字病院小児科) \\ (2)富山医科薬科大学小児科) \\ (3)いからし小児科（加茂市)）
}

\section{はじめに}

我々が経皮酸素分圧值を指標としたヒスタミ ン吸入閾值（RT-Hist）を乳幼児から学童期の 喘息児で測定したところ, RT-Hist と重症度は 4-6 歳では相関しないが 7-9歳では相関がみ られ，中等症以上の状態が続くと有意に気道過 敏性が六進した1)。また，3歳以下でこれまで3 回以上の喘鳴を繰り返す喘息児および 2 回まで の喘鳴を認めた喘息疑い例では RT-Hist が $2500 \mu \mathrm{g} / \mathrm{ml}$ 以上と正常範囲の症例がみられ

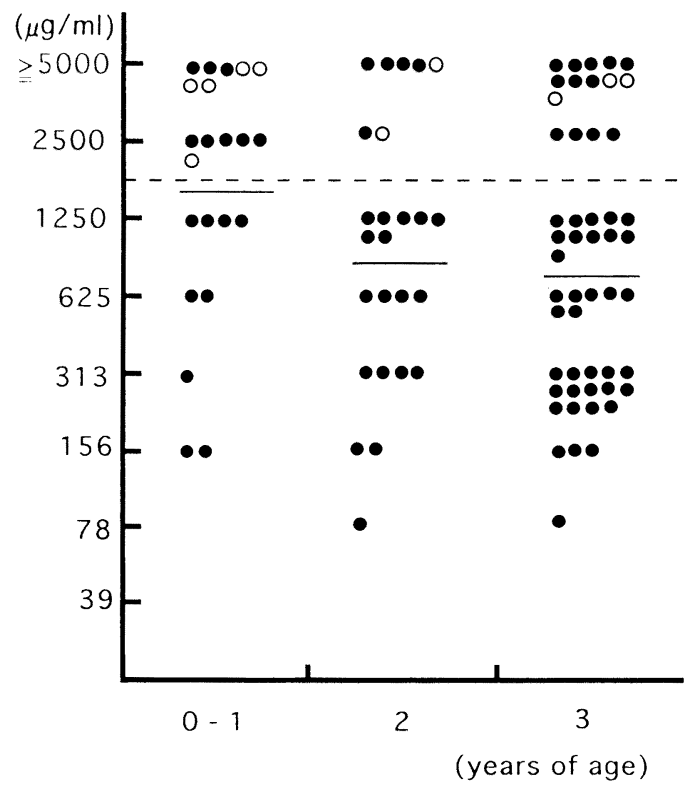

Fig. 1 Respiratory threshold to histamine in bronchial asthma $(\bullet)$ and suspicious asthma (O).
(Fig. 1)，乳児喘息では気道過敏性は未だ固定 化されていないと考えられた2)。これらの結果 より，乳児喘息において発症早期より喘息発作 の予防, 治療を行うことは, 気道過敏性の元進 をくいとめ, 重症化阻止に重要と思われる。

\section{急性発作の治療（Fig. 2)}

乳児喘息では努力性呼吸は陥没呼吸, 多呼吸 として表現され, 呼吸困難の程度は生活の状態 で判断しなければならない。さらに治療に協力 を期待できない上に，気管支拡張剂に対する反 応性が悪く，症状が急激に悪化し，脱水や低酸 素血症に陷りやすいなどの特徵を有する。以下， 日本アレルギー学会の小児気管支喘息の治療ガ イドラインを踏まえて，乳児喘息の治療につい て触れてみる。

1) 小発作の治療。 $\beta_{2}$ 刺激薬，テオフィリン製 剂を単独あるいは併用で経口投与する。2)中発 作の治療。 $\beta_{2}$ 刺激薬をネブライザ一吸入, さら にアミノフィリンの点滴静注を行う。乳児では テオフィリンクリアランスが低值を示すため血 中濃度のモニタリングを行うことが望ましい。 3) 大発作の治療。酸素吸入下で $\beta_{2}$ 刺激薬をネブ ライザー吸入する。アミノフィリン持続点滴を 行い, ステロイド薬の静注を行う。酸塩基平衡 の破綻や脱水を改善させる。イソプロテレノー 儿持続吸入療法に関して我々は $\ell$ 体（プロタ） ール L) を用いて検討したところ，低年齢で Woodのスコアが高值を示し, $\mathrm{SpO}_{2}$ 低值を示 す場合効果が不十分であり，本療法は呼吸不全 に至る前に行っている3)。ネブライザー吸入に 関しては，乳児では啼泣しているとほとんど肺 
Oral and/or inhaled beta2-agonist, Oral theophylline
Inhaled beta2-agonist IV aminophylline Hydration

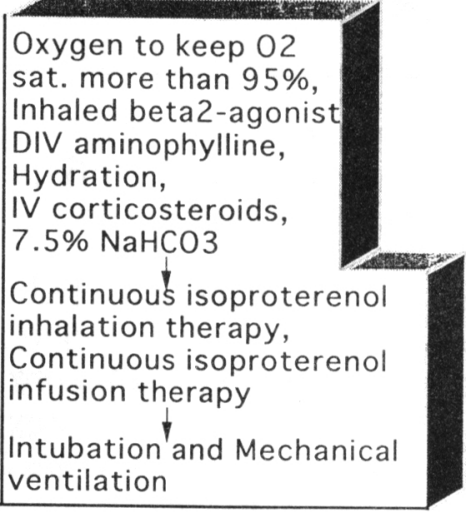

Severe

Mild Moderate

Fig. 2 Management of acute exacerbations of infantile asthma.

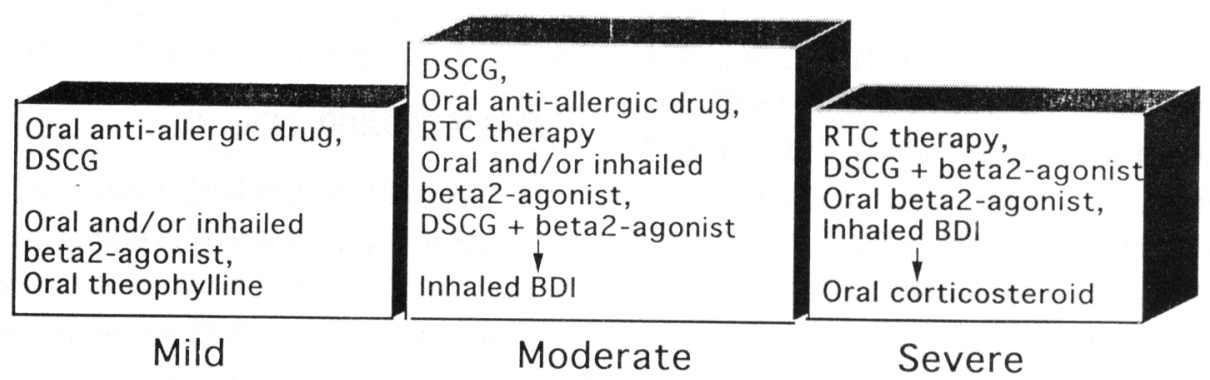

Fig. 3 Management of chronic infantile asthma.

に薬物が負荷されず，さらに安静換気下でも年 長児に比べ低值を示すことより ${ }^{4)}$, 今後 $\beta_{2}$ 刺激 薬の投与量について検討する必要があると思わ る。

軽症（小発作持続状態）では，経口抗アレル ギー薬および DSCGの吸入を使用する。中等症 (中発作持続状態) では, 上記治療に加えてテオ フィリン製剤による RTC 療法, $\beta_{2}$ 刺激薬の頓 用あるいは定期の経口あるいは吸入, DSCG と $\beta_{2}$ 刺激薬の混合液の定期吸入のいずれか，ある いは併用が選択される。上記治療でもコントロ ール不能な場合, BDI 吸入をスペイサーを用い て行う。重症、難治例 (大発作持続状態) には, $\mathrm{DSCG}$ と $\beta_{2}$ 刺激薬の混合液と BDI の吸入回数 を増やす。

\section{慢性喘息の薬物療法（Fig. 3) 非発作時の治療}

1)抗原除去。喘息に影響を与える環境物質と して室内アレルゲン（ダニ，昆虫，力ビ，ペッ 卜), 化学あるいは物理的刺激物質がある。我々 は, 寝具中の Der I + IIが30 $\mu \mathrm{g} / \mathrm{g}$ dust 以上に なると発作が増加し, その減量には掃除機を使 つた掃除が有効であることを報告している5。 乳児では食物により皮膚症状とともに喘息症状 がみられる場合があり，明らかなとき制限食を 要する。2)減感作療法および鍛練療法。乳児に おいては一般的には行われない。3)薬物治療。 慢性喘息の治療より，はじめにステロイドの内 服，吸入の減量・中止をはかり，数力月単位で 観察し，ステップダウンを行う。 


\section{おわりに}

乳児喘息では気管支拡張剤に対する反応性が 悪く, 急速に症状が悪化する場合が見られるこ とより，治療のステップを高めに設定すること が必要と思われる。しかし, 全身へのステロイ ドはもちろんのこと，BDIにおいてもいまだど の程度まで乳児において骨や成長に対して影響 がないかについてのデータが少ないことより， 安易な使用は避けるべきと思われる。今後, 抗 コリン剂や喀痰溶解剂なども含めて, 各種薬剤 の乳児喘息での有効性に関するデータが蓄積さ れることにより, 乳児喘息治療のガイドライン がつくられるものと考える。

\section{参考文献}

1）足立雄一, 沢井昌子, 佐伯陽子, 他：年小児 気管支喘息に扔ける気道過敏性の経時的変化 の検討，アレルギー 37 (7)：404-410, 1988.

2 ) 足立雄一, 村上巧啓, 松野正知, 他: 乳幼児 に抢けるヒスタミン吸入閾值の臨床的検討, アレルギー 37(5) : 250-255, 1988.

3 ) 足立雄一, 吉住 昭, 五十嵐隆夫, 他：小児 気管支喘息重症発作に対するイソプロテレノ 一ル持続吸入療法，アレルギー 41(6)：654661, 1992.

4 ) Gyokei Murakami, Takao Igarashi, Yuichi Adachi, et al. : Measurement of bronchial hyperreactivity in infants and preschool children using a new method, Ann Allergy 64(4) : 383-387, 1990.

5 ）松野正知, 吉住 昭, 高柳 幹, 他：電気掃 除機を用いたふとん掃除の有効性に関する検 討，アレルギー 41(8)：1218, 1992. 